\title{
Managing Internal Resource for Sustainability: A Case of Indian Family Business
}

\author{
Mary Metilda R, Abraham Varughese
}

\begin{abstract}
Family Business plays an important role in any economy to enhance employment in low income strata of population. They are included in house hold enterprises where the resources of business and owner is inseparable. A few family baseness had grown from informal level to formal due to consistent growth while a few had extinct. The extinction and survival of small family business ignite a curiosity to identify reasons for it. The inseparability in resources between business and owner limit the growth trajectory and scope for availing finance from formal system. This compels the small family business to depend on own resources or to rise fund on personal risk. The population in this research is grocery traders as it is one of the prominent in family business as it can be started as a part of residence, all family members can contribute, need of less expertise and lower investment. This paper analyse how small family business manage resources in time when they are in need. The research is conducted in Coimbatore District in Tamilnadu and the sample size is 392. It is a longitudinal survey as the data is collected over a period of one year. The shops were classified on two parameters, floor area and daily sales and measures for comparison are Net Trading Cycle, Gross Margin Return on Investment ( GMROI) and Net Profit Ratio (NPR). Family business use Resource Bootstrapping and Bricolage (RBB) strategies to overcome resource scarcity or to reduce the cash outflow which include the use of own fund, premises, vehicles and family members. The Paper explain how the RBB strategies add to the value addition through reducing operating expenses.
\end{abstract}

Index Terms: Grocery retailers, informal enterprises, Resource bootstrapping, revenue to expense ratio, return on investment.

\section{INTRODUCTION}

Role of Family business in economy

Family business are entrepreneurships that use own resources for business. It is a sort of necessity entrepreneurship as they opt business as a last sort in choosing a career choice or occupation. The role of family business in economy, especially in grocery retailing, is to widen the supply chain network to rural areas to reduce the possibility of food desert in India. The root causes for the

Revised Manuscript Received on July 08, 2019.

Mary Metilda R, Professor and Head of the Department , Sri Ramakrishna Engineering College, Coimbatore.

Mobile: 9442952055 Email:metilda@srec.ac.in.

Abraham Varughese, Assistant Professor, KristujayantiCollege ( Autonomous), Bangalore, India , mobile: 0919886872544 , Email. abrahamoperations@gmail.com. emergence of food desert is the travelling distance and accessibility to the shops which may increase due to the closure of shops in rural areas (Paula Dutko, 2012).The family business has its own unique success propositions like long hours of working, function from own premises to sustain in competitive environment. Hence, the family business has a social responsibility and commitment to make the life of rural economy more powerful and growing in enhancing self-employment.

The resource management of informal family business is different from organised model which are resource self-reliant. The management of resource scarcity can be explained using two theories.

Resource bootstrapping and bricolage: two behavioural strategies in resource management

Resource bootstrapping is a strategy to substitute an expensive or a scarce resource with a cheap resource while bricolage is a strategy to manage a resource scarcity with what is readily available in hand at that time. a few resources constrain that informal enterprises face are, capital, spatial, expertise, and legal assistance. This paper attempts to analyse how resource bootstrapping and bricolage are used as the managerial strategies by informal enterprises taking the grocery retailers as a special case. Grocery retail shops spread over everywhere people live. Hence, population density, distance to travel, demographic factors of shops, size of the retail shops in terms of floor area, capital used, inventory range are the controlling variables in this research. Sales, total cost, and profitability are the dependant variables used to compare the performance of different strata of retailers and how resource bootstrapping and bricolage influence these variables is to be analysed.

The main challenges in analysing the operational efficiency of informal enterprises is, information asymmetry, inseparability of business from owner, heterogeneity in resources used, low education, and fear to respond to surveys. Hence the data on operational activities must be collected through continuous interaction and observation.

\section{Research Methodology}

The data is collected from the family business in Coimbatore and sample size is 392 shops. The prime data was collected using a longitudinal data collection process in which the respondents were observed continuously to 
understand how these shops manage resource scarcity. Multiple regression model is used to explain the factors that influence the profitability of the firms.

\section{Findings}

The response to different parameters of operations by the retails vary significantly with the size of the retail shop.

\begin{tabular}{|c|c|c|c|}
\hline \multirow{2}{*}{$\begin{array}{l}\quad \text { Co } \\
\text { ntroll } \\
\text { ing } \\
\text { varia } \\
\text { ble }\end{array}$} & \multicolumn{2}{|c|}{$\begin{array}{l}\text { Resource bootstrapping } \\
\text { and their benefit to the shop }\end{array}$} & \multirow{2}{*}{$\begin{array}{c}\text { strategies } \\
\text { Large }\end{array}$} \\
\hline & Small & $\begin{array}{l}\text { Medi } \\
\text { um }\end{array}$ & \\
\hline $\begin{array}{l}\mathrm{Ca} \\
\text { pital }\end{array}$ & $\begin{array}{l}\text { From friends, } \\
\text { relatives, or own } \\
\text { saving, low } \\
\text { interest, or no } \\
\text { interest. Most of } \\
\text { the shops are } \\
\text { informal }\end{array}$ & $\begin{array}{l}\text { Own } \\
\text { fund } \\
\text { and } \\
\text { loans. }\end{array}$ & \begin{tabular}{l}
\multicolumn{1}{c}{ Own } \\
fund and \\
loans. \\
Registere \\
d \\
retailers. \\
Avail \\
overdraft \\
facility \\
and \\
facility.
\end{tabular} \\
\hline $\begin{array}{l}\text { inv } \\
\text { entor } \\
\mathrm{y}\end{array}$ & $\begin{array}{l}\text { Lower storage } \\
\text { capacity. } \\
\text { Focussed stock } \\
\text { kit Unit mix } \\
\text { based on } \\
\text { demand, only } \\
\text { fast moving } \\
\text { items based } \\
\text { local demand, } \\
\text { short net trading } \\
\text { cycle, low } \\
\text { content of slow } \\
\text { moving } \\
\text { products. But } \\
\text { the cost of } \\
\text { procurement } \\
\text { increases with } \\
\text { number } \\
\text { procurements } \\
\text { per unit period. } \\
\text { Customization } \\
\text { is the important } \\
\text { facility }\end{array}$ & $\begin{array}{l}\text { More } \\
\text { general } \\
\text { ised } \\
\text { stock } \\
\text { kit unit } \\
\text { mix, } \\
\text { not } \\
\text { strictly } \\
\text { based } \\
\text { on local } \\
\text { deman } \\
\text { d } \\
\text { frequen } \\
\text { t } \\
\text { deman } \\
\text { d. More } \\
\text { space } \\
\text { needed } \\
\text { for } \\
\text { storage, } \\
\text { content } \\
\text { of slow } \\
\text { moving } \\
\text { product } \\
\text { s } \\
\text { increas } \\
\text { e, net } \\
\text { trading } \\
\text { cycle } \\
\text { elongat } \\
\text { es, but } \\
\text { saves } \\
\text { cost }\end{array}$ & $\begin{array}{l}\text { Wide } \\
\text { range of } \\
\text { merchan } \\
\text { dise to } \\
\text { attract } \\
\text { high net } \\
\text { worth } \\
\text { customer } \\
\text { s. } \\
\text { Inventory } \\
\text { planning } \\
\text { is based } \\
\text { on } \\
\text { forecasti } \\
\text { ng. } \\
\text { Possibilit } \\
\text { y for } \\
\text { phantom } \\
\text { products } \\
\text { and } \\
\text { wastage } \\
\text { due to } \\
\text { expiry of } \\
\text { life. Very } \\
\text { lengthy } \\
\text { net } \\
\text { trading } \\
\text { cycle. } \\
\text { More } \\
\text { investme } \\
\text { nt on } \\
\text { additiona } \\
1 \text { storage }\end{array}$ \\
\hline
\end{tabular}




\begin{tabular}{|c|c|c|c|}
\hline & in the proximity & $\begin{array}{l}\text { Hence, } \\
\text { sales } \\
\text { are } \\
\text { inconsi } \\
\text { stent. } \\
\text { The } \\
\text { average } \\
\text { bill size } \\
\text { is } \\
\text { mediu } \\
\text { m. }\end{array}$ & $\begin{array}{l}\text { time } \\
\text { constrain } \\
\text { and } \\
\text { convenie } \\
\text { nce, } \\
\text { customer } \\
\text { s from } \\
\text { city } \\
\text { prefer to } \\
\text { reduce } \\
\text { number } \\
\text { of } \\
\text { procurem } \\
\text { ents but } \\
\text { prefer } \\
\text { bulk } \\
\text { purchase }\end{array}$ \\
\hline $\begin{array}{l}\text { Di } \\
\text { stanc } \\
\text { e } \\
\text { from } \\
\text { city } \\
\text { or } \\
\text { town }\end{array}$ & $\begin{array}{l}\text { The carriage } \\
\text { in increases and } \\
\text { hence the total } \\
\text { cost increases. } \\
\text { But sales will } \\
\text { increase as it } \\
\text { would be } \\
\text { inviable for the } \\
\text { local customers } \\
\text { to travel long to } \\
\text { buy daily needs. } \\
\text { Door delivery } \\
\text { further ease the } \\
\text { customers. }\end{array}$ & \begin{tabular}{l}
\multicolumn{1}{c}{ The } \\
carriag \\
e \\
inward \\
reduces \\
but the \\
sales \\
will be \\
limited \\
to daily \\
commu \\
ters. \\
Hence \\
holiday \\
s, \\
strikes, \\
climate \\
change \\
s etc. \\
will \\
affect \\
adverse \\
ly. \\
Week \\
end \\
sales \\
may \\
depend \\
on local \\
populat \\
ion \\
density.
\end{tabular} & $\begin{array}{l}\text { Week } \\
\text { end sales } \\
\text { increase } \\
\text { as the } \\
\text { customer } \\
\text { s to visit } \\
\text { with } \\
\text { family in } \\
\text { their } \\
\text { vehicle. } \\
\text { The } \\
\text { shopping } \\
\text { experien } \\
\text { ce and } \\
\text { economic } \\
\text { al use of } \\
\text { vehicle } \\
\text { persuade } \\
\text { them to } \\
\text { complete } \\
\text { the } \\
\text { purchase } \\
\text { for the } \\
\text { next } \\
\text { week. } \\
\text { This will } \\
\text { increase } \\
\text { sales }\end{array}$ \\
\hline $\begin{array}{l}\quad \mathrm{Nu} \\
\text { mber } \\
\text { of } \\
\text { shops } \\
\text { withi } \\
\mathrm{n} \text { the } \\
\text { proxi } \\
\text { mity }\end{array}$ & $\begin{array}{l}\text { Credit } \\
\text { facility, door } \\
\text { delivery etc. will } \\
\text { limit the switch } \\
\text { over of } \\
\text { customers one } \\
\text { shop to another. }\end{array}$ & \begin{tabular}{l}
\multicolumn{1}{c}{ The } \\
compet \\
ition \\
will \\
affect \\
the \\
busines \\
s \\
signific
\end{tabular} & \begin{tabular}{l}
\multicolumn{1}{c}{ Deep } \\
discount \\
sales, \\
seasonal \\
offers , \\
week end \\
offers \\
pull the \\
customer
\end{tabular} \\
\hline
\end{tabular}

\begin{tabular}{|c|c|c|c|}
\hline & & $\begin{array}{l}\text { antly. } \\
\text { Hence } \\
\text { the } \\
\text { unique } \\
\text { ness in } \\
\text { assortm } \\
\text { ent, } \\
\text { goodwi } \\
\text { ll, price } \\
\text { etc. } \\
\text { influen } \\
\text { ce the } \\
\text { footfall. } \\
\text {. }\end{array}$ & $\mathrm{S}$ \\
\hline $\begin{array}{l}\quad \mathrm{Ca} \\
\text { sh } \\
\text { purc } \\
\text { hase } \\
\text { and } \\
\text { purc } \\
\text { hase } \\
\text { disco } \\
\text { unts }\end{array}$ & $\begin{array}{l}\text { Being small, } \\
\text { the quantity } \\
\text { purchased is } \\
\text { small and lack } \\
\text { of credit facility, } \\
\text { cash purchase is } \\
\text { essential which } \\
\text { in turn depends } \\
\text { on the collection } \\
\text { of receivables, } \\
\text { cash sales. This } \\
\text { pressurise for } \\
\text { free flow of cash } \\
\text { or to depend on } \\
\text { informal money } \\
\text { lenders for fund } \\
\text { at high interest. } \\
\text { Cash discounts } \\
\text { will be } \\
\text { negligible. }\end{array}$ & $\begin{array}{l}\text { Bulk } \\
\text { purchas } \\
\text { e and } \\
\text { credit } \\
\text { purchas } \\
\text { e due to } \\
\text { high } \\
\text { volume } \\
\text { will not } \\
\text { affect } \\
\text { the } \\
\text { procure } \\
\text { ment } \\
\text { schedul } \\
\text { e but } \\
\text { the } \\
\text { bargain } \\
\text { ing } \\
\text { power } \\
\text { will } \\
\text { improv } \\
\text { e the } \\
\text { profitab } \\
\text { ility. If } \\
\text { receiva } \\
\text { bles are } \\
\text { not } \\
\text { collecte } \\
\mathrm{d} \quad \text { in } \\
\text { time, } \\
\text { paymen } \\
\mathrm{t} \\
\text { schedul } \\
\text { e will } \\
\text { be } \\
\text { affected } \\
\text {. }\end{array}$ & $\begin{array}{l}\quad \text { Since } \\
\text { modern } \\
\text { retailers } \\
\text { get credit } \\
\text { facility } \\
\text { and large } \\
\text { volume } \\
\text { purchase } \\
\text { will } \\
\text { enhance } \\
\text { the } \\
\text { bargainin } \\
\text { g power } \\
\text { and } \\
\text { profit } \\
\text { increases } \\
\text {. But the } \\
\text { deep } \\
\text { discounts } \\
\text { and } \\
\text { advertise } \\
\text { ments } \\
\text { will } \\
\text { reduce } \\
\text { the profit } \\
\text { earned } \\
\text { from } \\
\text { bulk } \\
\text { purchasi } \\
\text { ng. } \\
\text { Hence } \\
\text { control of } \\
\text { operation } \\
\text { al } \\
\text { expense } \\
\text { is } \\
\text { necessary } \\
\text {. }\end{array}$ \\
\hline $\begin{array}{l}\quad \mathrm{Ve} \\
\text { ndor } \\
\text { suppl } \\
\text { ied } \\
\text { prod } \\
\text { ucts } \\
\end{array}$ & $\begin{array}{l}\text { The supply } \\
\text { from local } \\
\text { producers, } \\
\text { farmers and van } \\
\text { suppliers } \\
\text { improve the }\end{array}$ & $\begin{array}{l}\quad \text { The } \\
\text { supply } \\
\text { from } \\
\text { local } \\
\text { produc } \\
\text { ers, }\end{array}$ & $\begin{array}{l}\quad \text { Moder } \\
\mathrm{n} \text { format } \\
\text { with } \\
\text { large }\end{array}$ \\
\hline
\end{tabular}




\begin{tabular}{|c|c|c|c|}
\hline & $\begin{array}{l}\text { inventory level } \\
\text { and the retailer } \\
\text { get a fixed } \\
\text { period to sell the } \\
\text { product and pay } \\
\text { the price. }\end{array}$ & $\begin{array}{l}\text { farmers } \\
\text { and van } \\
\text { supplie } \\
\text { rs } \\
\text { improv } \\
\text { e the } \\
\text { invento } \\
\text { ry level } \\
\text { and the } \\
\text { retailer } \\
\text { get a } \\
\text { fixed } \\
\text { period } \\
\text { to sell } \\
\text { the } \\
\text { product } \\
\text { and pay } \\
\text { the } \\
\text { price }\end{array}$ & $\begin{array}{l}\text { spatial } \\
\text { charges, } \\
\text { commissi } \\
\text { on, and } \\
\text { credit } \\
\text { facility. } \\
\quad \text { This } \\
\text { will } \\
\text { increase } \\
\text { availabili } \\
\text { ty of new } \\
\text { and } \\
\text { unique } \\
\text { brands in } \\
\text { store. . }\end{array}$ \\
\hline $\begin{array}{l}\text { lab } \\
\text { our }\end{array}$ & $\begin{array}{l}\text { Self-labour, } \\
\text { part time labour } \\
\text { or engagement } \\
\text { of family } \\
\text { members. this } \\
\text { reduce cost of } \\
\text { operation. }\end{array}$ & \begin{tabular}{l}
\multicolumn{1}{r}{ Labo } \\
ur \\
charges \\
are \\
controll \\
ed by \\
using \\
part \\
time \\
employ \\
ees for \\
hourly \\
basis \\
and \\
piece \\
work \\
rate for \\
packin \\
g into \\
standar \\
dised \\
packets
\end{tabular} & $\begin{array}{l}\text { A } \\
\text { combinat } \\
\text { ion of } \\
\text { part time, } \\
\text { piece-rat } \\
\text { e, and } \\
\text { full time } \\
\text { labour } \\
\text { are used. }\end{array}$ \\
\hline $\begin{array}{l}\quad T r \\
\text { ansp } \\
\text { ortati } \\
\text { on } \\
\text { cost }\end{array}$ & $\begin{array}{l}\text { it may be } \\
\text { brought in } \\
\text { public transport } \\
\text { or own vehicle } \\
\text { or even in small } \\
\text { vehicles }\end{array}$ & $\begin{array}{l}\text { other } \\
\text { retailer } \\
\mathrm{s} \text { or } \\
\text { reduce } \\
\text { the } \\
\text { number } \\
\text { of } \\
\text { carriag } \\
\text { e in by } \\
\text { purchas } \\
\text { ing } \\
\text { bulk } \\
\text { matchi } \\
\text { ng to } \\
\text { the } \\
\text { carriag }\end{array}$ & $\begin{array}{l}\text { Gener } \\
\text { ally, the } \\
\text { supplier } \\
\text { will } \\
\text { deliver at } \\
\text { warehous } \\
\text { es as } \\
\text { large } \\
\text { shops } \\
\text { buy in } \\
\text { large } \\
\text { quantity. }\end{array}$ \\
\hline
\end{tabular}

\begin{tabular}{|c|c|c|c|}
\hline & & $\begin{array}{l}\text { e } \\
\text { capacit } \\
\text { y }\end{array}$ & \\
\hline $\begin{array}{l}\text { W } \\
\text { astag } \\
\mathrm{e}\end{array}$ & $\begin{array}{l}\text { Wastage is } \\
\text { very high as } \\
\text { major content of } \\
\text { the merchandise } \\
\text { is perishable. } \\
\text { But shrinkage } \\
\text { cost and cost of } \\
\text { phantom cost } \\
\text { are negligible }\end{array}$ & $\begin{array}{l}\quad \text { Shri } \\
\text { nkage } \\
\text { cost } \\
\text { and } \\
\text { spill } \\
\text { over } \\
\text { are } \\
\text { high, } \\
\text { cost of } \\
\text { phanto } \\
\text { m } \\
\text { product } \\
\text { s is } \\
\text { signific } \\
\text { ant. }\end{array}$ & $\begin{array}{l}\text { Wasta } \\
\text { ge cost is } \\
\text { high but } \\
\text { expired } \\
\text { products } \\
\text { and slow. }\end{array}$ \\
\hline
\end{tabular}

\section{CONCLUSION}

Resource bootstrapping and bricolage are two behavioural strategies seen among entrepreneurs to overcome the resource constrains when they are either scarce or expensive. All entrepreneurs use one or another type of resource bootstrapping methods but varies from one person to another and one industry to another industry. They can be temporary or permanent. The factors that influence the selection of resource bootstrapping or bricolage, are size of the firm, age of the firm, location, capital used etc.

The results of this research also support the findings of Ebben(2006), Winborg (2008), Padachi (2011), Fatoki (2013) , Auken and Neely (2006) and Lehm and Little (2005). There is a positive effect of resource strategies on profitability. The extension of research to the informal retail formats also support the findings of previous researches.

\section{REFERENCES}

1. Baker, T., \& Nelson, R. E. (2005). "Creating something from Nothing: Resource Construction through Entrepreneurial Bricolage". Administrative Science Quarterly 50 ,3, 329-366.

2. $\quad$ Bruce R. Barringer and R. Duane Ireland (2010). " Entrepreneurship: Successfully Launching New Ventures, 3rd Edition”, Pearson Prentice Hall

3. Jay Barney (1991). "Firm Resources and Sustained Competitive Advantage". Journal of Management, 17, 1, 99-120

4. Brealey, R. A., Myers, S. C. \& Allen, F. (2006) "Corporate Finance", 8th edition, McGraw-Hill Irwin

5. Candida G. Brush, Tatiana S. Manolova and Linda F. Edelman (2008). "Separated by a Common Language? Entrepreneurship Research Across the Atlantic". Entrepreneurship Theory and Practice 32, 2, 249-266.

6. Colin c. Williams (2015), "Tackling Entrepreneurship in the Informal Sector: An overview of the Policy Options, Approaches and Measures", Journal of Developmental Entrepreneurship, 20,1, ISSN 1084 9467, http://dx.doi.org/10.1142/s1084946715500065

7. Cornwall, J. (2010). "Bootstrapping. (1st ed.)". New Jersey: Pearson Education.

8. Cyert, R and March, J (1963). " The Behavioural Theory of the Firm”. Eaglewood Cliffs, NJ: Prentice Hall.

9. Fisher, M.L., A. Raman. 2010. The New Science of Retailing. Harvard Business School Press, Boston, MA. 
10. Fox, Edward J., Alan L. Montgomery and Leonard M. Lodish (2004), "Consumer Shopping and Spending Across Retail Formats," Journal of Business, 77 ,2, S25-S60.

11. Global Entrepreneurship Monitor (2016), Global Report 15/16

12. Jay J. Ebben, (2009) "Bootstrapping and the financial condition of small firms". International Journal of Entrepreneurial Behavior\& Research. $15.4,346-363$

13. John Peponis, Douglas Allen, Steve French,Martin Scoppa, Jason Brown (2007). "Street Connectivity and Urban Density: spatial measures and their correlation". Proceedings, 6th International Space Syntax Symposium, İstanbul,

14. KessevenPadachi, Carole Howorth, MS Narasimhan (2012) “Working capital financing preferences: The case of Mauritian manufacturing small and medium-sized enterprises (SMEs)", Asian Academy of Management Journal of Accounting and Finance, 8,1,125-157

15. L. Naing, T. Winn, B.N. Rusli(2006), Practical Issues in Calculating the Sample Size for Prevalence Studies, Archives of Orofacial Sciences 2006; 1: 9-14

16. Oliver E Williamson (1981), "The Economics of the Organization " Transaction Cost Approach, American Journal of Sociology”, 87, 3 , 548-577

17. ÖzgeÖner( 2015). "Retail City: The Relationship between Place Attractiveness and Accessibility to Shops", IFN Working Paper No. 1055 , Research Institute of Industrial Economics

19. Paula Dutko, M. V. (2012). Characteristics and Influential Factors of Food Deserts, Economic ResearchReport. United States Department of Agriculture. Retrieved from http://www.ers.usda.gov/data-products/food-desert-locator.aspx

20. Pfeffer, J., \&Salancik, G.R (1978). "The External Control of Organizations: A Resource Dependence Perspective". New York: Harper and Row,

21. Porter, M.E (2008). "The five competitive forces that shape strategy". Harvard Business Review, 86,1,:78-93.

22. The 2016 Global Retail Development Index (2016). "Global Retail Expansion at a Cross Roads",ATKearney

23. Walters (1991) "Assessing the Impact of Retail Price Promotions on Product Substitution, Complementarity Purchase, and Inter Store Sales Displacement," Journal of Marketing," 55 (April), 17-28.

24. Winborg, J. (2008). "Use of financial bootstrapping in new businesses: a question of last resort?" Venture Capital, 11,1, 71-83.

25. Winborg, J., \&Landstrom, H. (2001). "Financial Bootstrapping in Small Businesses: Examining Small Business Managers’ Resource Acquisition Behaviours". Journal of Business Venturing, 16, 235-25

\section{AUTHORS PROFILE}

Mary Metilda R Professor and Head of the Department , Sri Ramakrishna Engineering College, Coimbatore Mobile: 9442952055 Email:metilda@srec.ac.in.

Abraham Varughese Assistant Professor, KristujayantiCollege ( Autonomous), Bangalore, India , mobile: 0919886872544 , Email. abrahamoperations@gmail.com. 